\title{
The life satisfaction approach to valuing public goods: The case of terrorism
}

\section{Journal Article}

Author(s):

Frey, Bruno S.; Lüchinger, Simon; Stutzer, Alois

Publication date:

2009-03

Permanent link:

https://doi.org/10.3929/ethz-b-000022027

Rights / license:

In Copyright - Non-Commercial Use Permitted

Originally published in:

Public Choice 138(3-4), https://doi.org/10.1007/s11127-008-9361-3 


\title{
The life satisfaction approach to valuing public goods: The case of terrorism
}

\author{
Bruno S. Frey • Simon Luechinger • Alois Stutzer
}

Received: 25 January 2008 / Accepted: 5 August 2008 / Published online: 19 September 2008

(C) Springer Science+Business Media, LLC 2008

\begin{abstract}
Terrorism has large social costs that are difficult to quantify for the well-known problems of eliciting people's preferences for public goods. We use the LSA to assess these costs in utility and monetary terms. Based on combined cross-section time-series data, we estimate the costs of terrorism for France and the British Isles. We find large negative effects of terrorism on life satisfaction that translate into considerable compensating surpluses for a hypothetical reduction in terrorism, in particular for the serious conflict in Northern Ireland. The effects of terrorism are robust and differ across groups in accordance with prior expectations.
\end{abstract}

Keywords LSA · Non-market valuation · Cost-benefit analysis $\cdot$ Subjective well-being · Terrorism

JEL Classification I31 $\cdot$ H56 - D61

\section{Introduction}

Terrorism has large social costs. It is undisputed that fear, grief and mourning, as well as the negative economic consequences of terrorist activities, reduce people's welfare. However,

This is a substantially revised version of our original paper with the same title based on an extended data basis.

B.S. Frey $(\varangle) \cdot$ S. Luechinger

Institute for Empirical Research in Economics, University of Zurich, Winterthurerstr. 30, 8006 Zurich, Switzerland

e-mail: bsfrey@iew.uzh.ch

S. Luechinger

e-mail: sluechinger@iew.uzh.ch

\section{A. Stutzer}

Department of Business and Economics, University of Basel, Petersgraben 51, 4003 Basel, Switzerland e-mail: alois.stutzer@unibas.ch 
how valuable is freedom from terrorism? Security, or the absence of terrorism, is a fundamental public good and one of the primary justifications for the existence of the state. Its provision competes with other public goods, and agents want to know its valuation relative to private goods and other public services. When the costs imposed on people by terrorist activities are known, the government can be expected to make better decisions on how many resources should be allocated to deal with terrorism. ${ }^{1}$ This holds even if the government is not viewed as a social-welfare maximizing agent, but is seen to act in a setting characterized by political competition. However, it is commonplace that individuals have no incentive to disclose their true demand for non-excludable goods; it is advantageous to understate demand when it positively affects contribution requirements and to overstate demand otherwise. Therefore, some economists are very pessimistic as to whether it is possible to assess people's preferences for public goods and bads:

"[T]he very essence of the public goods problem is that there is no way these preferences can be determined" (Due and Friedlaender 1973, p. 53; emphasis added).

In contrast to this negative view, a vast literature exists, reflecting extensive research and considerable progress in valuing public goods in monetary terms. Essentially, two avenues have been pursued: revealed preference methods (examples are the hedonic method or the defense expenditure approach) on the one hand and stated preference methods (especially the contingent valuation method) on the other hand. However, despite their ingenuity, these approaches have serious flaws, especially in the context of terrorism (see the earlier working paper version of this paper for an extensive discussion of the promises and pitfalls of the standard non-market valuation techniques).

In this paper, we propose the Life Satisfaction Approach (LSA) as a potentially effective complementary method to value the psychic costs of terrorism. The LSA correlates the degree of public goods or public bads with individuals' reported subjective well-being and evaluates them directly in terms of life satisfaction, as well as relative to the effect of income on life satisfaction. This approach obviates some of the major difficulties inherent in both the revealed preference and stated preference methods. As it is not based on observed behavior, the underlying assumptions are less restrictive and non-use values can-to a certain extent—be measured. Furthermore, individuals are not asked to value the public good directly, but to evaluate their general life satisfaction. This is presumably a cognitively less demanding task, does not evoke answers considered desirable by the persons asked, and there is no reason to expect strategic behavior. ${ }^{2}$

This paper proceeds in two steps. First, we explain the key characteristics of the LSA and discuss conceptual issues (Sect. 2). Second, we present our application to terrorism (Sect. 3). The utility losses caused by terrorist activities are estimated and monetized for

\footnotetext{
${ }^{1}$ For an overview and further references on the economics of terrorism, see e.g. Enders and Sandler (1995), Frey and Luechinger (2003), Frey (2004), Enders and Sandler (2006) or the special issue of Public Choice on terrorism with contributions by Kurrild-Klitgaard et al. (2006), Rowley (2006) and Shughart (2006) among others. An alternative approach for valuing the benefits from homeland security is offered in Sandler et al. (2008).

${ }^{2}$ Of course, the possibility of strategic answering behavior cannot be completely ruled out with the LSA. For example, it may be that respondents living in terrorized regions strategically report an overly low life satisfaction, anticipating that researchers will use their reported life satisfaction several years later to valueamong other things - national security. However, although such a scenario is theoretically possible, we do not think that it is very likely. The crucial argument is that with the LSA, reported life satisfaction is related ex post to terrorist activity by researchers.
} 
France and the British Isles $^{3}$ using combined cross-section time-series data. France is the Western European country with the highest number of recorded international terrorist incidents in the last quarter of the 20th century. ${ }^{4}$ Similarly, the terrorist conflict in Northern Ireland, the so-called 'Troubles', affected not only Northern Ireland but also Great Britain and the Republic of Ireland. Individuals in a region prone to terrorist activities are shown to suffer considerable utility losses. Section 4 offers concluding remarks.

\section{The LSA to valuing public goods}

\subsection{The basic concept}

Influenced by the positivistic movement in philosophy, standard economics is based on an "objectivistic" position (see, e.g., Sen 1986). Individual utility is inferred from actual behavior and subjectivist experience, as captured by surveys, is rejected as being not objectively observable and therefore "unscientific". The axiomatic approach holds that the choices made by individuals provide all the information required to infer the utility of outcomes. However, this position restricts the questions that can be addressed. It is, for example, not possible to discriminate between competing theories that predict the same behavioral patterns, but differ in what they put forward as people's utility level (Frey and Stutzer 2005). Moreover, conceptions about individuals' preferences or utility functions remain vague and the valuation of public goods is hampered (Arrow 1958, pp. 8-9; Schelling 1968, pp. 143-144). Revealed preference methods cannot be applied in all cases of interest and non-use values leave no behavioral trace. It is, therefore, no accident that non-market valuation is a field in economics where surveys have been widely used.

The recent development of happiness research in economics (for surveys see Frey and Stutzer 2002a, 2002b; Di Tella and MacCulloch 2006; Clark et al. 2008) offers a complementary approach to the challenged revealed preference approach. Due to extensive work by numerous psychologists spanning many decades (see, e.g., Diener et al. 1999; Kahneman et al. 1999), the great progress made in the measurement of experienced utility has gained recognition. ${ }^{5}$ Thus, reported subjective well-being can serve as an empirically adequate and valid approximation for individually experienced welfare. Hence, it is an obvious and straightforward strategy to directly evaluate public goods in experienced utility terms. Moreover, by measuring the marginal utility of a public good or the marginal disutility of a public bad, as well as the marginal utility of income, the trade-off ratio between income and the public good can be calculated.

\footnotetext{
${ }^{3}$ Throughout the paper Great Britain refers to England, Scotland, Wales and several smaller islands, United Kingdom refers to Great Britain and Northern Ireland, and British Isles refers to the United Kingdom and the Republic of Ireland.

${ }^{4}$ According to RAND St. Andrews Chronology of International Terrorism (see Sect. 3.1 for a description), France had 520 international terrorist incidents in the period under consideration followed by the Federal Republic of Germany with 425. International terrorism is defined as terrorism involving citizens or the territory of more than one country.

${ }^{5}$ Experienced utility follows an interpretation of utility in hedonistic terms broadly understood. This interpretation contrasts with today's standard decision utility. Decision utility is a representation of preferences as derived from choices. We follow here the terminology proposed by Kahneman et al. (1997) to differentiate between the two concepts. There are many research questions where it is useful to take experienced utility measured by reported subjective well-being as a proxy for decision utility and vice versa. However, there is evidence indicating that, in certain situations, the two concepts systematically diverge (see e.g., Kahneman and Thaler 2006).
} 
In order to use life satisfaction data to value public goods, several necessary conditions have to be met that we make explicit in the following:

(i) Life satisfaction scores should contain information on the respondent's global evaluation of his or her life. It is necessary in other words, that life satisfaction not merely be an argument in the utility function, or a subutility function, as Kimball and Willis (2006) conjecture for measures of current affect.

(ii) Reported life satisfaction contains sufficient information (relative to noise) about true individual welfare that statistical research is fruitful. There is substantial evidence for this. Measures of reported subjective well-being passed a series of validation exercises, revealing, e.g., that people reporting high subjective well-being suffer less from hypertension (Blanchflower and Oswald 2007), or are less likely to commit suicide (Koivumaa-Honkanen et al. 2001). Moreover, reported life satisfaction is associated with activation asymmetry between the right and left prefrontal cortex and between the right and left amygdala (Urry et al. 2004).

(iii) Respondents' evaluations or appraisals of their life are meant to refer to present life across all domains. This focus on the present situation is often implied by the wording of the question, sometimes even including an extension like 'these days', 'now' or 'nowadays'.

(iv) Life satisfaction scores are reported on an ordinal scale. Using adequate statistical techniques like ordered probit or ordered logit, the ordinal information is sufficient to calculate a compensating surplus. However, in many applications, similar results are obtained when interpreting life satisfaction scores in cardinal terms (Frey and Stutzer 2000; Ferrer-i-Carbonell and Frijters 2004). This is also the case here. For ease of interpretation, we report results from least square regressions, and only refer to the results based on ordered probit regressions when presenting the results for the compensating surplus.

(v) A further key assumption refers to the comparability of life satisfaction data across groups of people and over time. The debate about interpersonal comparisons of wellbeing is far-ranging and elaborate in traditional welfare economics (see the contributions in Elster and Roemer 1991). There are two reasons why interpersonal comparability is less of an issue in the practical statistical application of the LSA. First, validity studies demonstrate that self-reports of subjective well-being are not just artifacts of individual specific response behavior but are related to shared standards of evaluation. For example, it has been found that people who rate themselves as happy are also rated as happy by friends and family members, as well as by spouses (e.g., Lepper 1998). Second, interpersonal comparability at the level of the single individual is not a necessary condition for valuing public goods in the proposed framework. It is sufficient if individual specific response frames do not systematically vary between different groups exposed to different levels of the public good, either across space or over time (e.g., Di Tella and MacCulloch 2006).

Under these assumptions, reported subjective well-being data can be used to assess individuals' preferences for public goods or externalities. The public good or the externality faced by an individual is included as an additional argument in a micro-econometric life satisfaction function. The estimated coefficients can be interpreted as marginal utilities of the public goods or the marginal disutilities of the public bads. Together with estimates for the marginal utility of income, the marginal rate of substitution between income and the public good can be calculated. Because the indifference curve over income and the public good is estimated directly, both relevant welfare measures, the equivalent surplus and the 
compensating surplus, can be computed even for inframarginal changes in the provision of the public good, without the need of auxiliary assumptions.

The LSA can be used to value a wide range of different public goods and bads, negative and positive externalities. Other studies based on a similar approach value externalities in the environmental realm. Examples are Van Praag and Baarsma (2005), assessing the effect of noise nuisance, Welsch (2002) and Luechinger (2008), estimating the effect of urban air pollution, and Luechinger and Raschky (2008), estimating the effect of flood disasters.

\subsection{Identification of utility changes}

As the preceding discussion suggests, the LSA is a potentially effective non-market valuation technique. In the following, we discuss several identification issues.

Omitted variables The LSA, like the revealed preference methods, is not immune to possible spurious correlations that are the result of omitted variables. If differences in selfreported life satisfaction are explained by cross-sectional differences in the public good, the estimates may be severely biased due to unobserved factors that co-vary with life satisfaction and the public good. For concreteness, consider terrorism. Imagine that people in terrorismprone regions report a lower life satisfaction, on average, than their counterparts in peaceful areas. Obviously, the regions differ from each other in various respects apart from the level of terrorist activities which are likely to influence the life satisfaction of the residents.

There are two ways of addressing this problem, though it cannot be completely resolved. First, the use of data with panel structure allows for the control of time-invariant regionspecific differences in life satisfaction, as well as area-independent temporal variations. Still, there may be time-variant regional effects that are correlated with happiness and the variable of concern, be it causal or not. For example, unemployment among young men and a general lack of opportunities during an economic downturn could further recruitment in terrorist groups and simultaneously depress life satisfaction in the affected regions. A second way, therefore, is to control for potentially collinear variables. However, a lack of adequate indicators often limits this procedure. Government reactions to terrorist activities, like curfews and curtailing of civil liberties, are likely to entail utility losses, but are difficult to operationalize. ${ }^{6}$

Compensating variation According to the premise of the hedonic method, individuals (without firm-specific investments and land ownership) exposed to a public bad or negative externalities are compensated in private markets, above all in the labor and housing market. This compensation has a countervailing effect on life satisfaction. In equilibrium, it is predicted that all public goods and public bads are capitalized in land (or rents) and wages and, consequently, life satisfaction is equalized across regions. However, this does not mean that the positive (negative) effect of a public good (bad) would not affect residents' well-being. It is just that a positive (negative) effect is equally distributed among them. Having said this, one has to take into consideration that, in reality, various restrictions, as well as moving and transaction costs, are likely to prevent complete arbitrage/equalization. Moreover, landowners (and employees with firm-specific investments) only have a costly exit option from locations that are negatively affected by a public bad or an externality. These residual effects are captured in reports of subjective well-being studied across regions (see also Van

\footnotetext{
${ }^{6} \mathrm{~A}$ third possibility is to instrument the variance of the public good, which is an almost hopeless undertaking in the case of terrorism.
} 
Praag and Baarsma 2005). However, the LSA is not restricted to these residual effects. In fact, it can be applied with any degree of compensation, as long as the channels of compensation are accounted for. As income, an important channel of compensation, is usually included in happiness functions, it is mainly rent differentials that could have an offsetting impact. The LSA is applied to the best advantage when there is little or no compensation. In these situations, the hedonic method breaks down. In contrast, the LSA works well. Biases due to compensation are most likely to be minor when annual intra- and interregional fluctuations are studied rather than variation across regions or countries. Empirically, this is possible in repeated cross-section analyses as, for example, conducted in our application in Sect. 3.

Spatial resolution A critical element of the analysis is the choice of spatial units or regions across which changes in life satisfaction are identified. For some externalities, the regional boundaries are obvious and the spatial choice does not pose any further problem. For example, although noise nuisance might be perceived in another manner by different people, it can be objectively measured and located. This is also true for other externalities that are of a technological kind, in particular externalities in the environmental realm. For social externalities, like externalities of education, cultural amenities, crime or terrorism, it is far more difficult to draw boundaries. Terrorism, for example, is explicitly "conceived to have far-reaching psychological repercussions beyond the immediate victim or target of the act" (Hoffman 1998, p. 38; see also Wilkinson 2000, p. 12, among others). In this case, one has to ask whether the climate of fear is confined to a legally or geographically defined region and where, if at all, empathy for the victims ends? This is a serious problem, as the estimated effects crucially depend on the spatial units chosen. Suppose, for example, a bomb explodes in the crowded centre of a small Northern Irish town and kills a large number of civilians. This terrorist incidence can affect people's well-being in different ways: for example, it can be taken as an indication of a new wave of terrorist attacks all over the British Isles and the atrocity shocks people everywhere to the same extent. In that case, it is quite likely that life satisfaction is depressed everywhere in Great Britain and in Northern Ireland to the same extent. The effect of the incident on individuals' well-being then cannot be identified across these two regions. If, on the other hand, only people in Northern Ireland are affected by an incident taking place in Northern Ireland, and no spillovers occur, the average decrease in life satisfaction due to terrorism can be fully identified. Therefore, the more incidents take place that only affect residents in one region, i.e., the lower the regional spillovers, the more appropriately the effects can be measured. However, the average treatment effect for people affected by terrorism is also underestimated if the spatial resolution is too coarse. In this latter case, people not affected by terrorism are wrongly taken into account as victims.

The discussion makes clear that knowledge of the actual situation and accurate definition of the regions across which the utility loss is identified are essential. In our empirical analysis, it seems reasonable to distinguish three regions for both France and the British Isles. The pattern of terrorist activity is relatively homogeneous within these regions but different across them. However, in order to test the sensitivity of the results to the choice of spatial resolution, we also replicate the analysis with data on a smaller scale. In the case of France, the three regions are Ile-de-France (which includes Paris), Provence-Alpes-Côte d'Azur (including Corsica) and the remainder of France. Many terrorist incidents are clearly confined to Paris. The city was plagued by attacks on foreign ambassadors, other diplomats and government officials, as well as the headquarters or domestic branches of firms. Similarly, most attacks of the Front de Libération Nationale de la Corse (FLNC) were perpetrated in Corsica rather than in continental France. In the case of the British Isles, the three regions are 
Great Britain, Northern Ireland and the Republic of Ireland. The pattern of terrorist activity clearly differs across these regions. Even though republican groups carried the conflict to Great Britain, Northern Ireland experienced violence on a much larger scale. Loyalist groups, such as the Ulster Volunteer Force (UVF), its splinter group the Loyalist Volunteer Force (ULF), and the Ulster Defence Association (UDA), limited their activities largely to Northern Ireland. In contrast to France, London has no special position with respect to terrorist activity (at least in the case of terrorist activity related to the Northern Ireland conflict). For example, the attacks with the highest death toll recorded in a single day occurred in Birmingham rather than in London (the Birmingham pub bombings of 1974).

\section{Effects of terrorism on life satisfaction}

\subsection{Data}

\subsubsection{Data sources and sample selection}

Our main variables are people's self-reported life satisfaction and income, as well as various indicators of terrorism. The former are taken from the Euro-Barometer Survey Series (1970-2002), which interviews a random cross-section sample of Europeans each year. Individual life satisfaction is elicited with the following question: "On the whole, are you very satisfied [4], fairly satisfied [3], not very satisfied [2], or not at all satisfied [1] with the life you lead?" The question was asked every year from 1973 to 2002 except for 1974, 1981, 1995 and 1996. The observations are assigned to the regions of interest, according to the respondents' place of residence. However, all observations from South-East France are excluded for 1979 and 1987 because they cannot be properly assigned to the different regions. Similarly, observations from the year 1973 are not included in the estimations for the British Isles, because the Northern Irish sub-sample is included in the sample of Great Britain.

The Euro-Barometer Survey Series also contains information concerning the income situation of the respondents; concretely, they are classified into between 6 and 12 classes of household income. The class size and number of classes varies considerably between countries and surveys. Therefore, we translate the original income class information into a number, which represents the value at the mid-point of the respective class interval. The values are converted into 2004 U.S. dollars. Because the highest income class is open-ended, respondents that fall into this income class are excluded. In order to capture the effect of household size on equivalence income, the square root of household size is included in the estimation equations. Furthermore, a set of personal characteristics is incorporated, including sex, age, number of children, marital status, employment status and the type of community in which the respondent lives. ${ }^{7}$ Respondents aged below 15 are excluded. The sample of the baseline regressions contains a total of 100,382 observations for which a complete set of data for the main variables is available. The number of observations is 30,244 for Great Britain, 7,891 for Northern Ireland, 24,185 for the Republic of Ireland, and 38,062 for France.

\footnotetext{
${ }^{7}$ Note that respondents' education is not included in the vector of personal characteristics. Education is highly correlated with lifetime income and, therefore, likely to take away explanatory power from the income variable. Further, in order to translate the utility losses caused by terrorism into monetary terms, the effect of income on life satisfaction per se is needed rather than the effect of within-education variation in income. However, the results are similar if education is controlled for.
} 
In order to capture the intensity of the terrorist activity in different regions and years, we use two distinct terrorism indicators: the number of reported terrorist attacks and the number of fatalities.

The first indicator is constructed on the basis of the RAND St. Andrews Chronology of International Terrorism (see, e.g., Hoffman and Hoffman 1995; made publicly available by the Oklahoma City National Memorial Institute for the Prevention of Terrorism on its homepage (www.mipt.org), the TWEED Terrorism in Western Europe: Event Data-project (see Engene 2007) and statistics on the Security Related Incidents in Northern Ireland provided by the Police Service of Northern Ireland (PSNI; www.psni.police.uk). The fatalities variable is constructed on the basis of the RAND data and a comprehensive list of deaths resulting from the conflict in Northern Ireland; the list has been compiled by Sutton (1994) and updated by the Conflict Archive on the Internet (www.cain.ulst.ac.uk). A detailed description of the terrorism indicators in the different regions is provided in the following Sects. 3.1.2 and 3.1.3.

\subsubsection{Terrorism indicators for France}

In the case of France, both the incident variable and the fatalities variable are entirely constructed on the basis of the RAND data. Every reported incident contains a short description with - in the majority of cases - the exact location of the incident. This allows us to assign the incidents (and fatalities) to a particular region. Only 11 incidents cannot be attributed to a region in the case of France, and 16 incidents in the case of the United Kingdom. The RAND data are restricted to international terrorism. However, international terrorism is broadly defined and includes attacks by Corsican separatist groups in France (as well as Northern Irish groups in Great Britain), as well as attacks by domestic terrorist groups whenever foreigners are involved. In France, for example, several attacks are recorded for which the Action Directe (AD) claimed credit, especially in the mid 1980s when the AD tried to ally itself with the German Rote Armee Fraktion (RAF). Some rather bizarre attacks, such as attacks on international computer firms by the Comité Liquidant ou Détournant les Ordinateurs (Committee for Liquidation of Computers, CLODO) or the bombing of gas pipelines by the Comite d'Action Viticole (Action Committee of Winegrowers, CAV), fall into the same category. But many state-sponsored terrorist activities also took place on French territory. An example is the murder of the former Iranian Prime Minister Shapour Bakhtiar in Paris in 1991 by a hit-squad which, according to the French investigating judge, was carried out under the direct orders of the Iranian regime (Wilkinson 2000, p. 66). Furthermore, France was plagued with the spillover of Basque terrorism into France and the spillover of activities by the Groupe Islamic Armée (GIA), as well as incidents related to the Middle East. Although international terrorism is broadly defined and plays an important role in France, the RAND data do not reflect the whole extent of the terror situation in France. For the years in our sample, the TWEED data, focusing on domestic terrorism, record 2,463 incidents; the RAND data, in contrast, record only 506 incidents. In the case of France, because the TWEED data contain no information on the geographical location (other than a country identifier) of an incident the RAND data cannot be supplemented with the TWEED data. For France, the following analysis rests on the assumptions that international terrorist attacks reflect the pattern and evolution of terrorism more generally or that it is mainly the international terrorist attacks that have negative effects on life satisfaction (probably because they are more severe). The latter conjecture is supported by the fact that international attacks are indeed more often fatal than domestic attacks. Although the RAND data contain fewer incidents than the TWEED data, more fatalities are recorded (147 in the RAND data compared to 111 


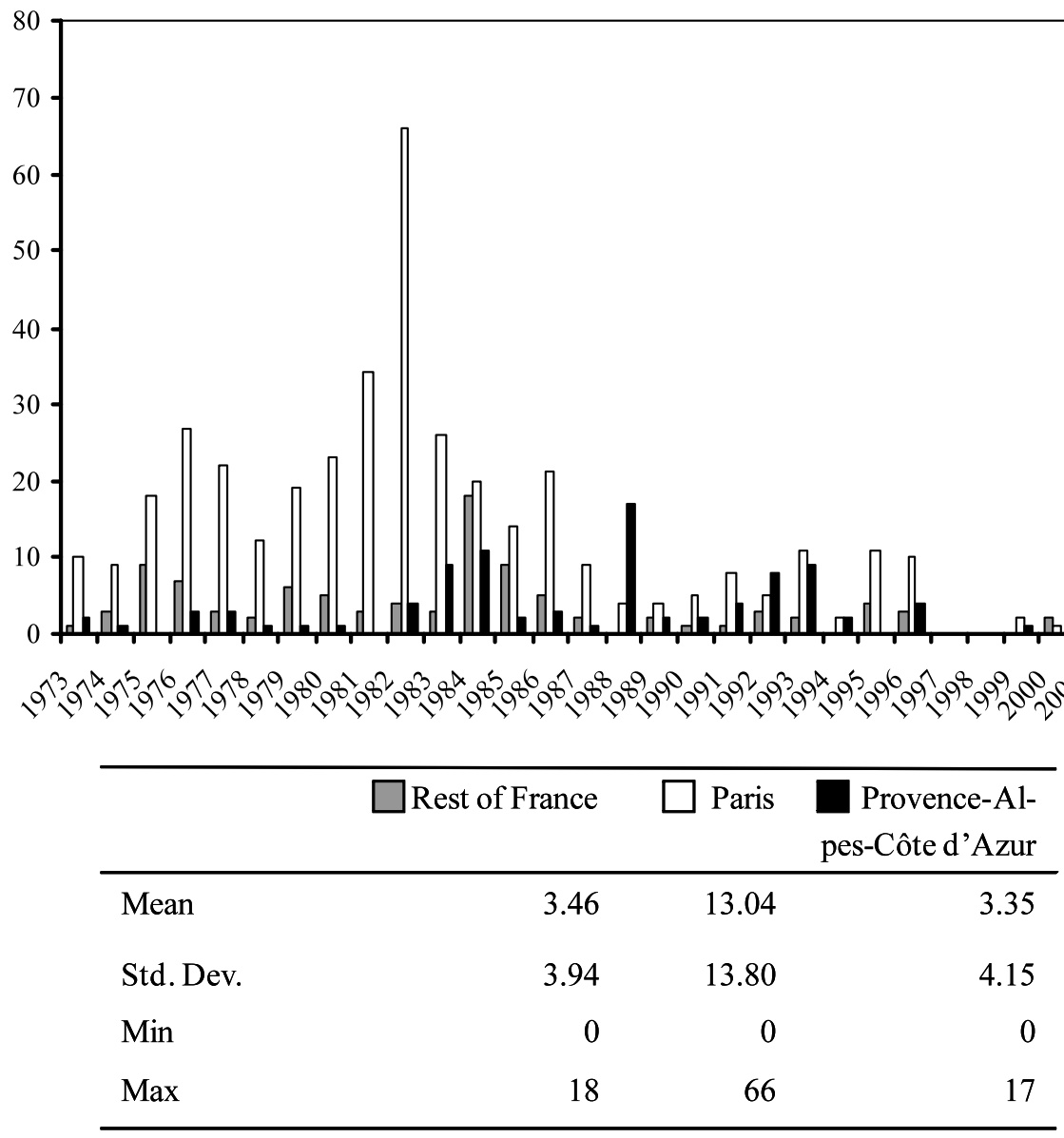

Fig. 1 Number of terrorist attacks in France 1973-2002. Source: RAND-St. Andrews Chronology of International Terrorism, provided by MIPT (www.mipt.org)

in the TWEED data). The former conjecture is supported by a relatively high correlation between the RAND data and the TWEED data. The correlation coefficient for the number of incidents is 0.67 and the correlation coefficient for the number of fatalities is 0.80 . Figures 1 and 2 depict the annual number of attacks and the annual number of fatalities for Paris, the region Provence-Alpes-Côte d'Azur and the remainder of France separately.

In Paris and the rest of France, there is a decrease in the number of attacks over the whole period; in the region Provence-Alpes-Côte d'Azur the number of attacks peaks in the second half of the 1980s. Compared to the other regions, Paris experienced around four times as many terrorist attacks.

The number of fatalities has been on the decrease in all three regions of France, in the remainder of France especially since the mid-1980s; again, most deaths occurred in Paris.

\subsubsection{Terrorism indicators for the British Isles}

Terrorist attacks The RAND data are also an important building block in constructing the terrorism variables for the British Isles. Most reported incidents in Great Britain were related 


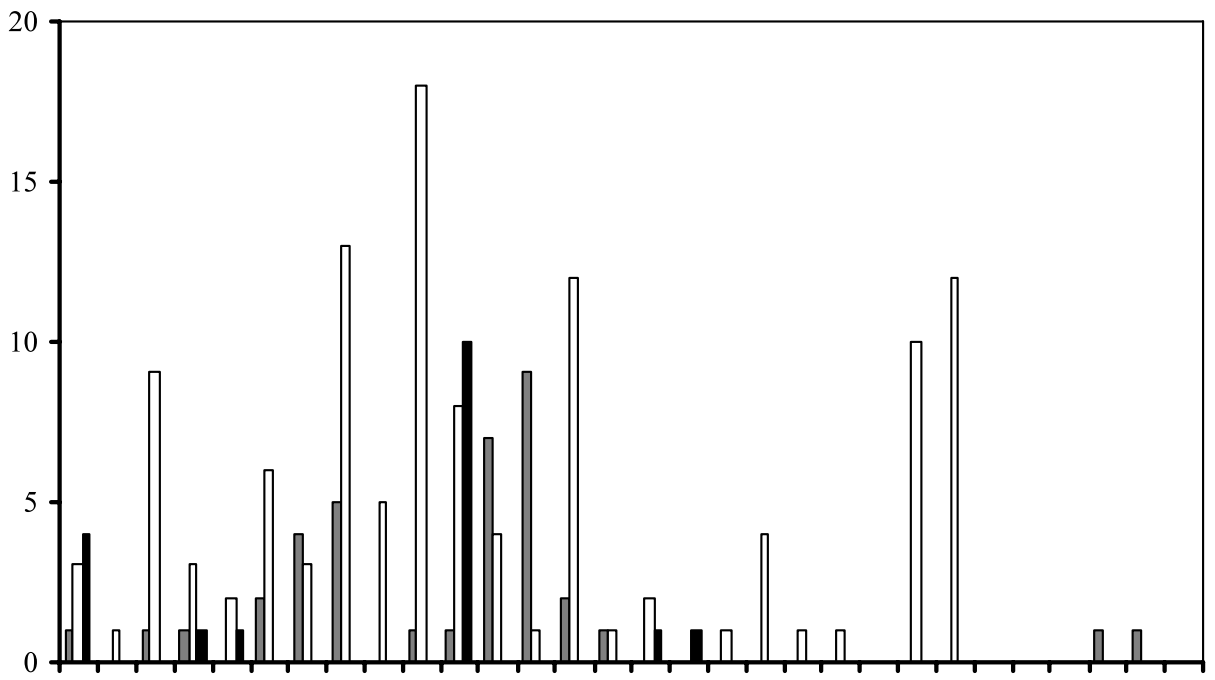

ง

\begin{tabular}{lrrr}
\hline & $\square$ Rest of France & $\square$ Paris & $\begin{array}{r}\text { Provence-Al- } \\
\text { pes-Côte d'Azur }\end{array}$ \\
\hline Mean & 1.42 & 3.58 & 0.70 \\
Std. Dev. & 2.32 & 4.73 & 2.07 \\
Min & 0 & 0 & 0 \\
Max & 9 & 18 & 10 \\
\hline
\end{tabular}

Fig. 2 Number of terrorist fatalities in France 1973-2002. Source: RAND-St. Andrews Chronology of International Terrorism, provided by MIPT (www.mipt.org)

to the Northern Ireland conflict, the "Troubles", and were committed by the Provisional Irish Republican Army (PIRA) and, to a lesser extent, by the Irish National Liberation Army (INLA). In 1972, the PIRA moved its bombing campaign to Great Britain. The first of many sporadic, but mostly spectacular, PIRA attacks was a bomb planted at Aldershot military barracks, killing seven and wounding five civilians belonging to the support staff, two of whom subsequently died. A comparison of the RAND data with the comprehensive list of fatalities compiled by Sutton (1994) shows that most attacks related to the Troubles that have been perpetrated in Great Britain are recorded in the RAND data: 87\% of the persons killed in Great Britain and recorded on Sutton's (1994) list, are also to be found in the RAND data. Moreover, the fraction of $87 \%$ even underestimates the congruence for fatal attacks because, in contrast to the RAND data, Sutton's (1994) list also contains terrorists who died in premature bomb explosions, political activists who died in hunger strikes and people who died in the aftermath of an attack. As an example, the RAND data record a bomb attack on March 27th, 1976, in a crowded exhibition hall in London that injured over 80 persons but killed no one, at least not immediately; Sutton's (1994) list, on the other hand, includes a 
woman who died on April 17th, 1976, three weeks after being injured in a bomb attack on an exhibition hall in London. Without question, both observations relate to the same event. Thus, the RAND data adequately capture Northern Irish terrorism in Great Britain. The same seems to be the case for the low-scale campaign of Welsh separatist groups, such as the Meibion Glyndwr.

While we are confident about the completeness of the RAND data for Great Britain, this is not the case for Northern Ireland and the Republic of Ireland. Only 3\% of the persons on Sutton's (1994) list killed in Northern Ireland and only 13\% of the persons on Sutton's (1994) list killed in the Republic of Ireland are recorded in the RAND data. Therefore, for the Republic of Ireland, we supplement the RAND data with the TWEED data. The TWEED data record a good deal of Northern Ireland-related incidents perpetrated in the Republic of Ireland. In order to avoid double counting of incidents, we exclude all incidents that are already recorded in the RAND data by comparing information concerning the date, perpetrator, target etc. of the incidents in the two datasets. ${ }^{8}$ The two datasets thus combined contain $26 \%$ of the persons on Sutton's (1994) list. Again, the $26 \%$ underestimate the true congruence for fatal attacks because a large number of persons on Sutton's (1994) list are victims of feuds in paramilitary groups, neutralized informers, abductees, or persons shot in armed robberies. For Northern Ireland itself, we use statistics on the number of incidents provided by the PSNI. The RAND data, focusing on international terrorism, almost entirely disregard incidents related to the Troubles if they are perpetrated in Northern Ireland. Figure 3 depicts the annual number of terrorist attacks for Great Britain, Northern Ireland and the Republic of Ireland.

In the Republic of Ireland, no clear pattern is visible. In Great Britain, the number of attacks peaked in the second half of the 1980s and early 1990s. Measured in terms of the number of attacks, the climax of violence in Northern Ireland occurred in the years before 1976 (or, alternatively, 1977). By far the most attacks were perpetrated in Northern Ireland; the number of attacks is around 960 times higher compared to the Republic of Ireland and around 80 times higher compared to Great Britain. In Fig. 3, the part of the bars for Great Britain above the partitions represents the number of attacks that are not related to the Northern Ireland conflict.

Terrorist fatalities For the British Isles, the variable on the number of fatalities is constructed on the basis of the RAND data and Sutton's (1994) list. The latter is not restricted to terrorism in particular, but includes political violence in general. Though the PIRA was always the highest taker of life, killing civilians, security forces and prison staff, the UDA and UVF were also very active; the interaction between these groups is generally referred to as sectarian 'tit-for-tat' exchanges (McKittrick and McVea 2001, pp. 109-110). Feuds, such as the ones between the Provisional and Official IRA in 1975 and between the UDA and UVF in 2000, as well as hunger strikes on the part of imprisoned IRA members in 1981, added to the death toll. On the other hand, a considerable number died at the hand of security forces. British paratroopers killed 14 demonstrators on the Bloody Sunday of 1972, British intelligence played a part in the Dublin and Monaghan bombing in 1974, and the army's undercover SAS regiment staged ambushes in which IRA members—and innocent bystanders-were shot, to name but a few examples. Sutton's (1994) list is one of the most

\footnotetext{
${ }^{8}$ In general, for several entries in the TWEED data, the information on the date of an attack is missing. However, for Ireland in our sample period, this information is available all incidents. For two incidents, only the month and year of the attack is known but information on the perpetrators and victims allows us to identify the attacks.
} 


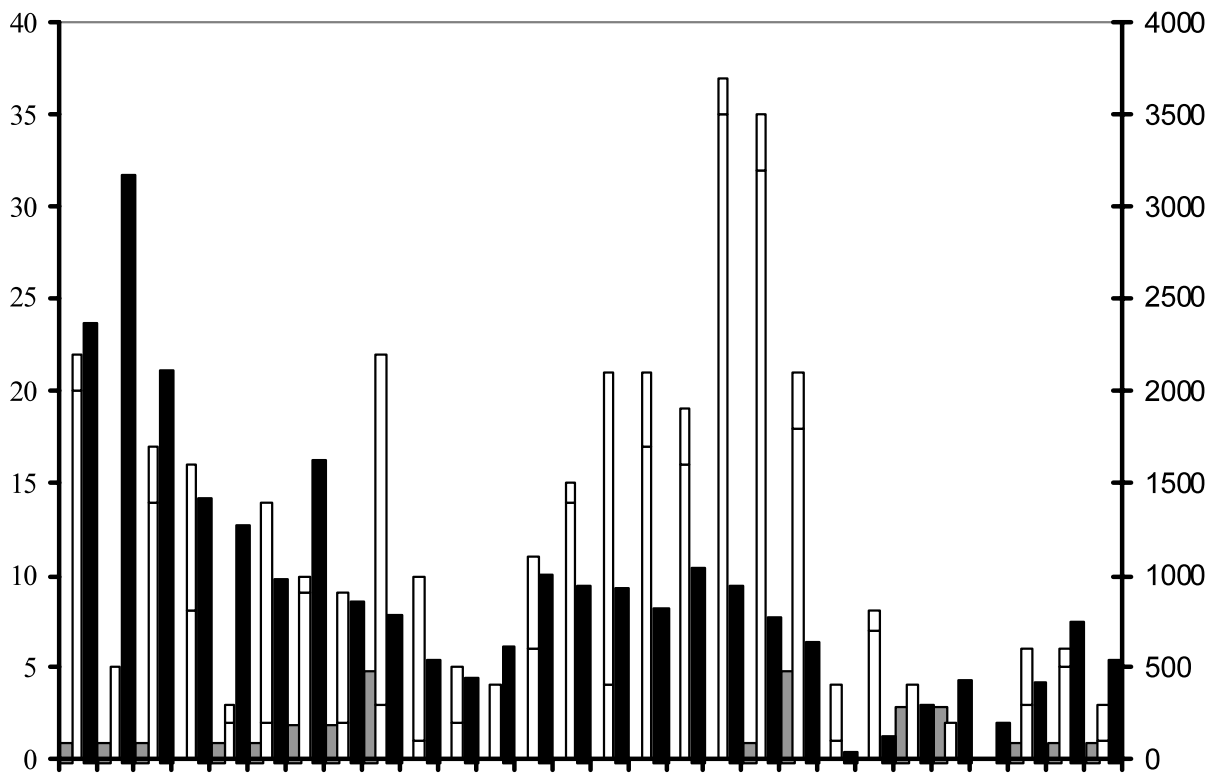

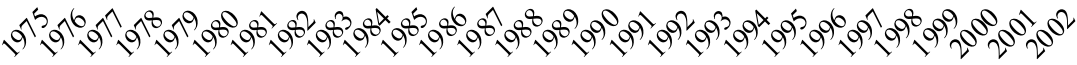

\begin{tabular}{lrrr}
\hline & $\square$ Ireland & $\Xi$ Great Britain & $\begin{array}{r}\text { Northern Ireland } \\
\text { (right ordinate) }\end{array}$ \\
\hline Mean & 1.08 & 13.12 & $1,035.88$ \\
Std. Dev. & 1.47 & 9.97 & 709.57 \\
Min & 0 & 0 & 232 \\
Max & 5 & 37 & 3,336 \\
\hline
\end{tabular}

Fig. 3 Number of terrorist attacks in the British Isles 1975-2002. For Great Britain, the bars above partition denote attacks not related to the 'Troubles'. Sources: RAND-St. Andrews Chronology of International Terrorism, provided by MIPT (www.mipt.org), Sutton (1994) and an updated version of the Sutton index provided by CAIN Web Service (www.cain.ulst.ac.uk), and statistics provided by the PSNI (www.psni.police.uk)

comprehensive published records on the deaths in the Troubles; it only excludes deaths indirectly due to the Troubles, such as those caused by army vehicles and heart attacks (see Fay et al. 1999, pp. 125-132, for a comparison of different lists). In combining the RAND data and Sutton's (1994) list, we again use the detailed information on the attacks in order to avoid double-counting. Deaths from attacks not related to the Northern Ireland conflict are limited to Great Britain (part of the bars for Great Britain in Fig. 4 above the partition) and occur neither in the Republic of Ireland nor Northern Ireland. The deaths are in large part related to spillover terrorism from the Middle East. The annual number of fatalities for Great Britain, Northern Ireland and the Republic of Ireland is shown in Fig. 4.

In the Republic of Ireland, the number of fatalities is decreasing; in Great Britain, no clear trend is visible, except for a small peak in the second half of the 1980s. Even more 


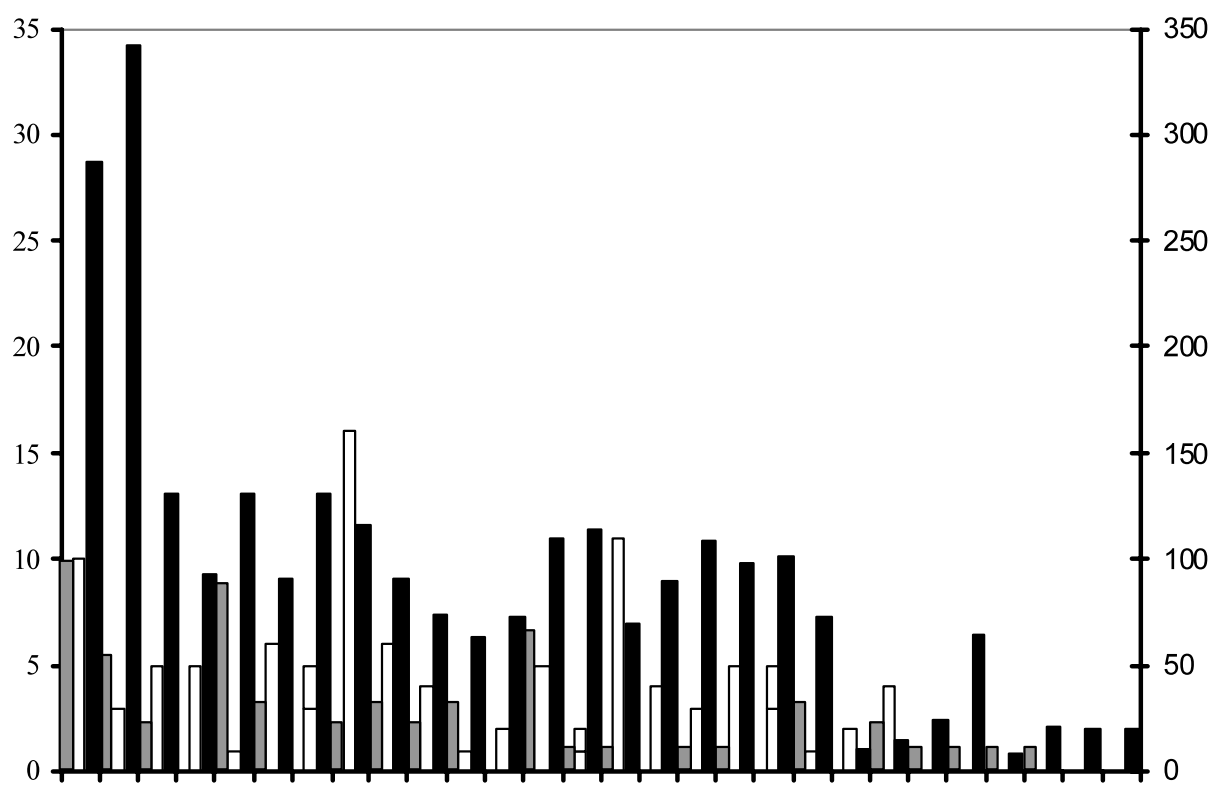

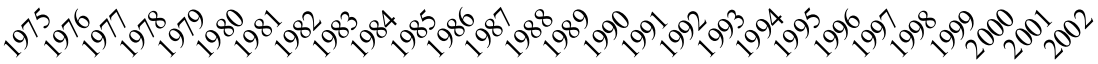

\begin{tabular}{lrrr}
\hline & $\square$ Ireland & 曰Great Britain & $\begin{array}{r}\text { Northern Ireland } \\
\text { (right ordinate) }\end{array}$ \\
\hline Mean & 2.16 & 3.8 & 80.84 \\
Std. Dev. & 2.46 & 3.95 & 62.99 \\
Min & 0 & 0 & 7 \\
Max & 9 & 16 & 287 \\
\hline
\end{tabular}

Fig. 4 Number of terrorist fatalities in the British Isles 1975-2002. For Great Britain, the bars above partition denote attacks not related to the 'Troubles'. Sources: RAND-St. Andrews Chronology of International Terrorism, provided by MIPT (www.mipt.org), Sutton (1994) and an updated version of the Sutton index provided by CAIN Web Service (www.cain.ulst.ac.uk), and statistics provided by the PSNI (www.psni.police.uk)

pronounced than the number of attacks, the number of fatalities in Northern Ireland plummeted in 1977. This corresponds to the observations of McKittrick and McVea (2001, p. 133) that 1977 "was a true turning-point in that violence fell dramatically, and would never again rise to the scale experienced in the 1971-76 period." Nevertheless, the number of fatalities remained high for the whole period under consideration. As with the number of attacks, Northern Ireland had the largest death toll, with between around 20 and 75 times the number of fatalities compared to Great Britain and the Republic of Ireland respectively.

\subsection{Empirical strategy}

Based on the described datasets, micro-econometric happiness functions are specified. Individual life satisfaction, $L S_{i r t}$, i.e., the life satisfaction of individual $i$ living in region $r$ at 
time $t$, is explained by differences in the level of terrorism, $T_{r t}$, across regions and over time, the log of individual household income, $m_{i r t}$, other personal characteristics $Z_{i r t}$, as well as region and time fixed effects $\rho_{r}$ and $\tau_{t}$, respectively. The specification is summarized in the following equation:

$$
L S_{i r t}=\beta_{0}+\beta_{1} T_{r t}+\beta_{2} \ln \left(m_{i r t}\right)+\beta_{3} Z_{i r t}+\rho_{r}+\tau_{t}+\varepsilon_{i r t} .
$$

Throughout the paper, we use a robust estimator of variance, because random disturbances are potentially correlated within groups or clusters, here cross-sectional units for a specific year. We estimate least square regressions, as well as ordered probit regressions due to the originally ordinal nature of the dependent variable. The results are qualitatively and quantitatively very similar for the two estimation approaches. For ease of interpretation, results from least square regressions are presented. ${ }^{9}$ However, the compensating surplus is calculated based on estimates from both kinds of regressions.

\subsection{Results}

\subsubsection{Basic results}

As can be seen from Table 1, terrorism negatively affects people's self-reported life satisfaction in a sizable and statistically significant way. An increase of one standard deviation in the number of recorded incidents, i.e., an increase of 154.03 incidents in the British Isles and an increase of 5.59 incidents in France, lowers life satisfaction by 0.012 and 0.013 points respectively on the four-point scale. An increase of one standard deviation in the number of recorded fatalities, i.e., an increase of 14.42 in the British Isles and of 1.78 in France, lowers life satisfaction by 0.009 points in both countries. These are large effects, indicating that a reduction of the terrorist threat by one standard deviation is equivalent to shifting between 0.9 and $1.3 \%$ of the population of France and the British Isles from, for example, not very satisfied [2] to fairly satisfied [3] with the life they lead. These effects in terms of life satisfaction offer one way of valuing a public bad with the LSA. They could be compared with estimates for other public goods or bads. For a valuation in monetary terms, estimates for the marginal utility of income have to be taken into consideration. Table 1 includes the respective estimations. Coefficients for (household) income are positive and highly statistically significant. The partial correlation between log income and life satisfaction for the British Isles is around 0.167 and around 0.250 for France. Thus, when income is doubled an average 0.116 points higher life satisfaction is reported in the British Isles, and an average 0.173 points higher life satisfaction in France.

For the estimates in Table 1, the cross-section variance is based on three regions per country. This geographical organization of the data is chosen on a priori reasoning with regard to diffusion of fear from terrorist attacks (see the discussion in Sect. 2.2 on the identification of utility changes). However, the Euro-Barometer Survey Series allow identification based on a higher resolution of the life satisfaction and terrorism data. For the British Isles, 13 regions can be differentiated: the Republic of Ireland, Northern Ireland, Scotland, Wales, the eight Standard Statistical Regions of England and Greater London. For France, the data can be disaggregated on the level of the 21 régions of continental France (including Corsica). Based on this higher resolution data, the coefficient for the number of incidents decreases by $1.4 \%$ to $-7.5 \mathrm{E}-5$ (t-value: -3.90 ) in the case of the British Isles, and by $19.7 \%$

\footnotetext{
${ }^{9}$ Results for ordered probit regressions are available from the authors on request.
} 


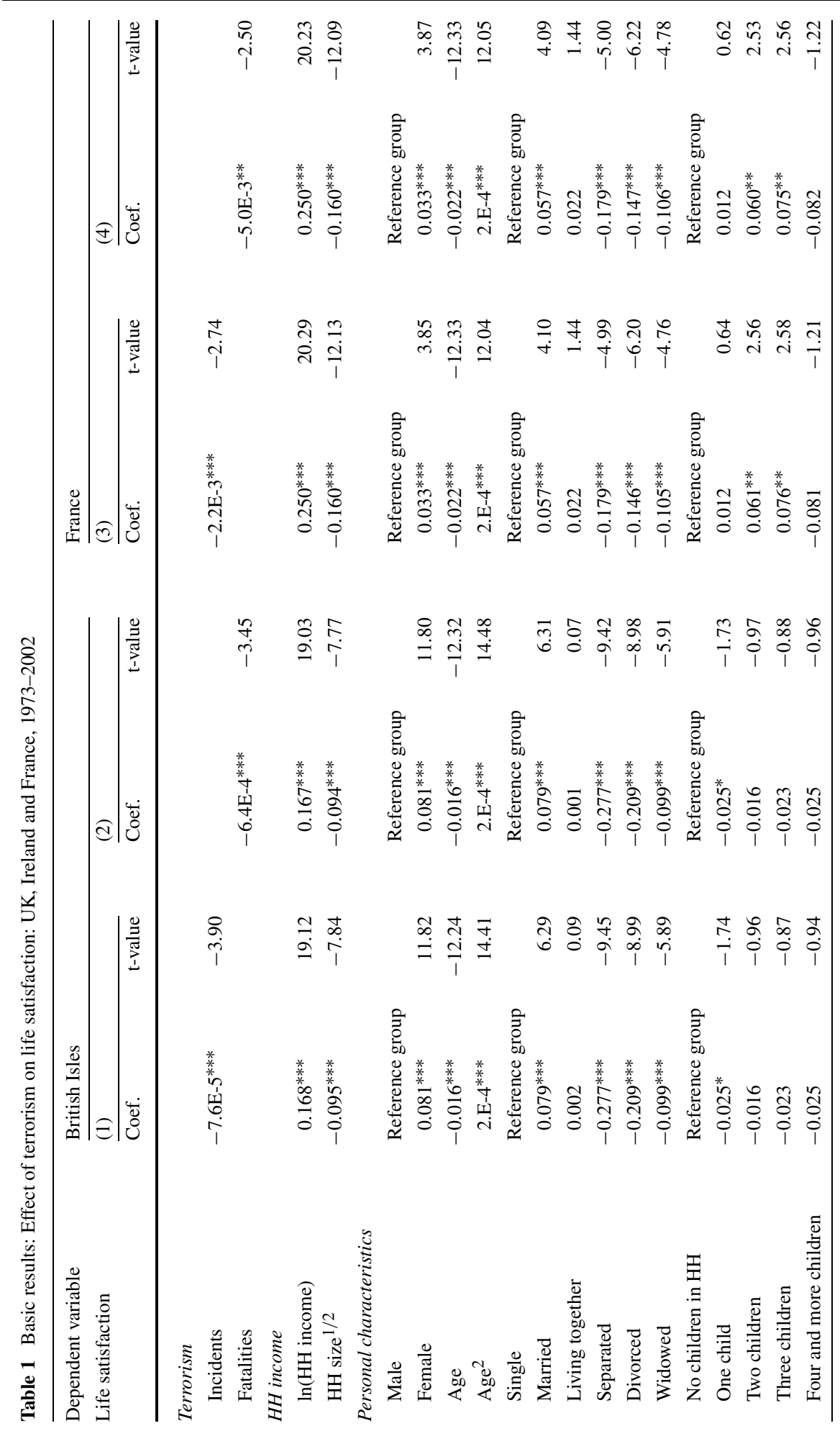




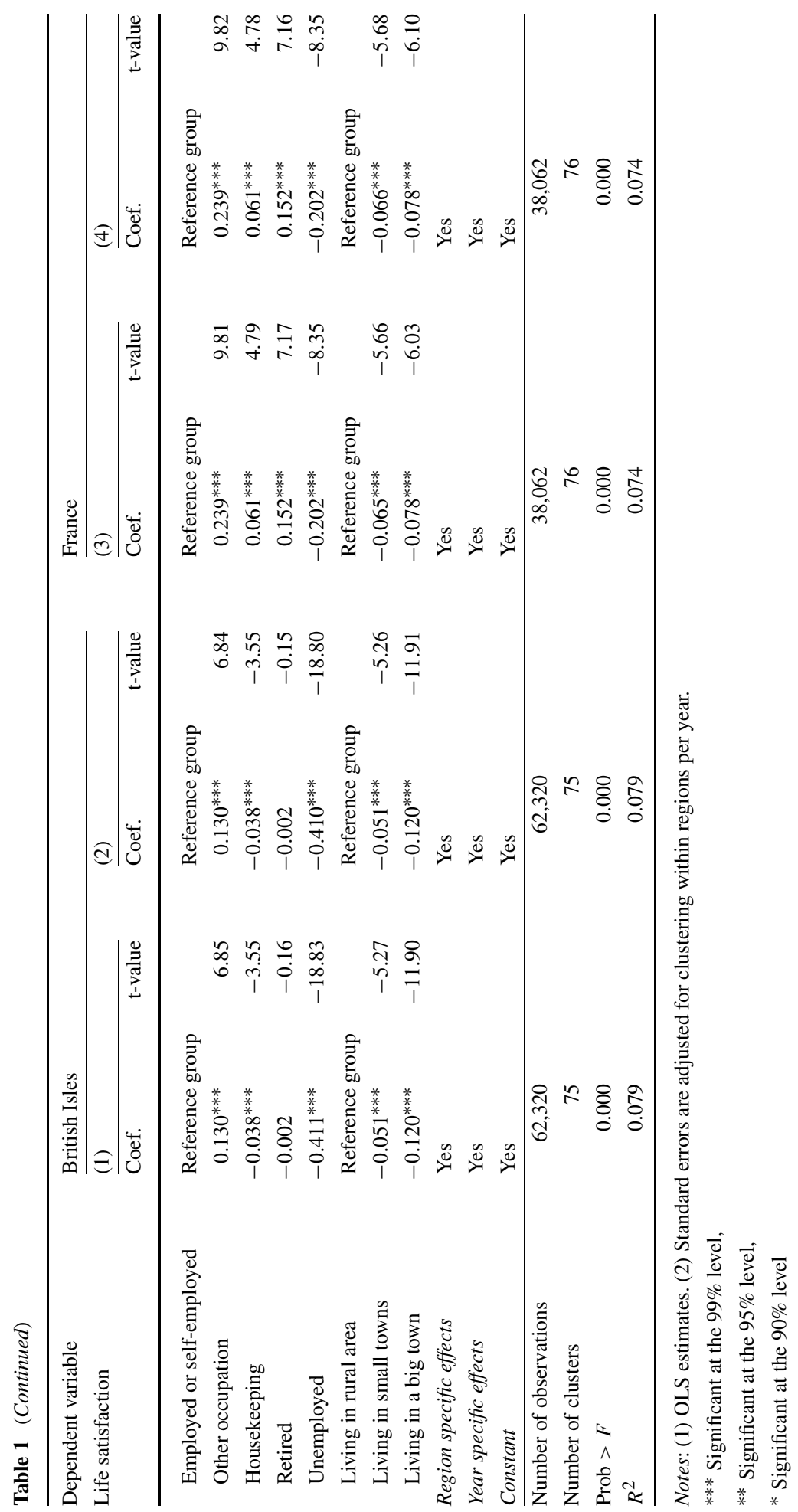


to $-1.8 \mathrm{E}-3$ (t-value: -2.74 ) in the case of France; the coefficient for the number of fatalities decreases by $1.3 \%$ to $-6.3 \mathrm{E}-4$ (t-value: -3.89 ) in the case of the British Isles, and by $25.4 \%$ to $-3.7 \mathrm{E}-3$ (t-value: -1.83 ) in the case of France..$^{10}$ Thus, highly disaggregated data persistently yield smaller estimates. In particular, this is the case for France. For the British Isles, the results are quite stable, probably because two of the three regions, Northern Ireland and the Republic of Ireland, are not further disaggregated.

In the following sub-sections, the baseline regressions are modified in order to check the validity and plausibility of the results and to derive further insights. First, we analyze the sensitivity of the estimates to the exclusion of individual region-year combinations. Second, we include variables capturing the economic situation, more precisely the growth rate of the GDP per capita and the unemployment rate, in order to address issues of simultaneity. Including these macro-economic variables also allows us to determine whether terrorism affects life satisfaction through contemporary effects on the economy. Third, as a further test to rule out that the effect of terrorism on life satisfaction is spurious, we interact terrorism with dummy variables for sub-groups of the population that are expected to suffer disproportionately from terrorism. In this way, the relatively insensitive group controls for other simultaneous and spatially coincident shocks.

\subsubsection{Sensitivity to the exclusion of single observations}

In 1982, an unprecedented number of 66 terrorist attacks took place in Paris, a number never reached in subsequent years (see Fig. 1). Similarly, in Northern Ireland, recorded fatalities in the years 1975 and 1976 by far outnumbered the fatalities of subsequent years (see Fig. 4). In order to investigate whether the negative correlation between terrorism and life satisfaction is largely driven by such observations, we repeatedly ran the regressions reported in Table 1, in each round excluding the observations for one region-year combination. For the British Isles, the coefficient for the number of incidents varies between -6.2E-5 (t-value: -3.89 ) and $-9.1 \mathrm{E}-5$ (t-value: -4.98$)$. Compared to the point estimate for the whole sample, the deviations are below $\pm 20 \%$. The coefficient for the number of fatalities varies between $-5.0 \mathrm{E}-4$ ( $\mathrm{t}$-value: -3.73 ) and $-8.2 \mathrm{E}-4$ ( $\mathrm{t}-\mathrm{value}$ : -3.86 ) or $+22 \%$ and $-28 \%$ compared to the whole sample. The coefficient for the number of incidents in France is less robust: it varies between $-1.9 \mathrm{E}-3$ (t-value: -3.32 ), a relative deviation of $14 \%$, and $-4.5 \mathrm{E}-3$ (t-value: $-2.98)$, a relative deviation of $-105 \%$. The large negative partial correlation is estimated if the observations for Paris in 1982 are excluded, i.e., the region and year with the highest number of attacks in France. The inclusion of these observations does not drive the negative correlation: on the contrary, a smaller negative effect is estimated when the full sample is taken into account. The coefficient for the number of fatalities in France varies between $-3.9 \mathrm{E}-3$ (t-value: -1.83 ) and $-6.0 \mathrm{E}-3$ (t-value: -3.19 ), i.e., relative deviations of $+30 \%$ and $-20 \%$. This statistical exercise shows that the coefficients are relatively stable, although there are clearly influential observations. An exception is the effect for the number of incidents in France. All estimates are comfortably below zero.

\subsubsection{Simultaneity and economic conditions}

One might argue that the negative correlation between terrorism and life satisfaction could be spurious because the state of the economy may be (negatively) correlated with the intensity of terrorist campaigns. If a high level of terrorist activity is generally accompanied

\footnotetext{
${ }^{10}$ Note that it is not possible to compare the t-values directly. Because robust standard errors are adjusted for clustering on region and year level, we have fewer degrees of freedom in the estimates based on the supra-regional level.
} 
by a slackening of the economy, people may report lower life satisfaction because they fear job reductions rather than terrorist attacks. Such a negative relationship between economic and terrorist activity is probable and can be due to two different causal processes. On the one hand, bad economic conditions and high levels of unemployment may facilitate the recruitment of rank and file activists. On the other hand, terrorism may dampen economic activity.

McKittrick and McVea (2001, p. 28) presume the first causal relationship for Northern Ireland when writing that "[i]t is scarcely a coincidence that some of the areas which featured prominently in the troubles [...] were among those where [...] high unemployment persisted." However, neither micro-level nor macro-level studies find evidence in support of this causal direction. Analyzing the characteristics of members of Israeli extremists, the Hezbollah, Hamas and Palestinian Islamic Jihad, Krueger and Maleckova (2003) and Berrebi (2003) find that poverty does not increase the propensity to participate in terrorism. If anything, terrorists, including suicide bombers, come from the ranks of the better off in society. Opinion polls conducted in the West Bank and Gaza strip find little evidence to suggest that a deteriorating economy increases support for terrorism. Time-series analyses fail to find a significant relationship between terrorism and GDP growth in Israel (Berrebi 2003; Krueger and Maleckova 2003). For Spain, time-series data for the tourism industry and terrorism indicate that terrorism affects tourism, but not the reverse (Enders and Sandler 1991). Finally, according to cross-country studies, poverty does not increase terrorism risk, as assessed by an international risk agency (Abadie 2006) or reflected in the number of international terrorist attacks (Piazza 2006), nor do perpetrators predominantly stem from poor countries (Krueger and Laitin 2003; Kurrild-Klitgaard et al. 2006). In sum, contrary to popular opinion, the preponderance of evidence suggests that there is no economic foundation for terrorism. Moreover, in the case of international terrorism, most perpetrators come from abroad. Economic conditions in the target region are therefore unlikely to influence the amount of terrorism.

The other causal connection is better documented. In the last few years, economic scholars have provided evidence for adverse effects of terrorism on various sectors of the economy and on overall economic activity (e.g., Abadie and Gardeazabal 2003; see Frey et al. 2007 for a review). Panel data estimates of the determinants of investment and employment in the Northern Ireland manufacturing sector indicate that variations in the intensity of political conflict have a large and significant impact on economic activity (Fielding 2003). A 20\% increase in the number of fatalities reduced investment in machinery and equipment by about $5.6 \%$ in equilibrium and construction investment by about $4.5 \%$; the short-term reductions in investment to a one-period increase in the number of fatalities by one standard-deviation is well over $25 \%$. The effects for employment are less pronounced and are sensitive to the data used.

In order to control for the potential simultaneity between high levels of political violence and a slackening of the economy, and in order to see whether part of the negative effect of terrorism on life satisfaction works through contemporaneous effects on economic activity, we include the growth rate of GDP per capita and the unemployment rate as additional control variables in the micro-econometric life satisfaction functions. We are confident that these two variables are able to adequately capture the general economic situation; the need for data which are regionally disaggregated and date back over several decades considerably restricts the availability of further data. Data for France are only available since 1976. Table 2 presents the results.

Coefficients for both indicators of terrorism remain of similar magnitude and statistical significance when business cycle effects are controlled for. Most coefficients even increase 


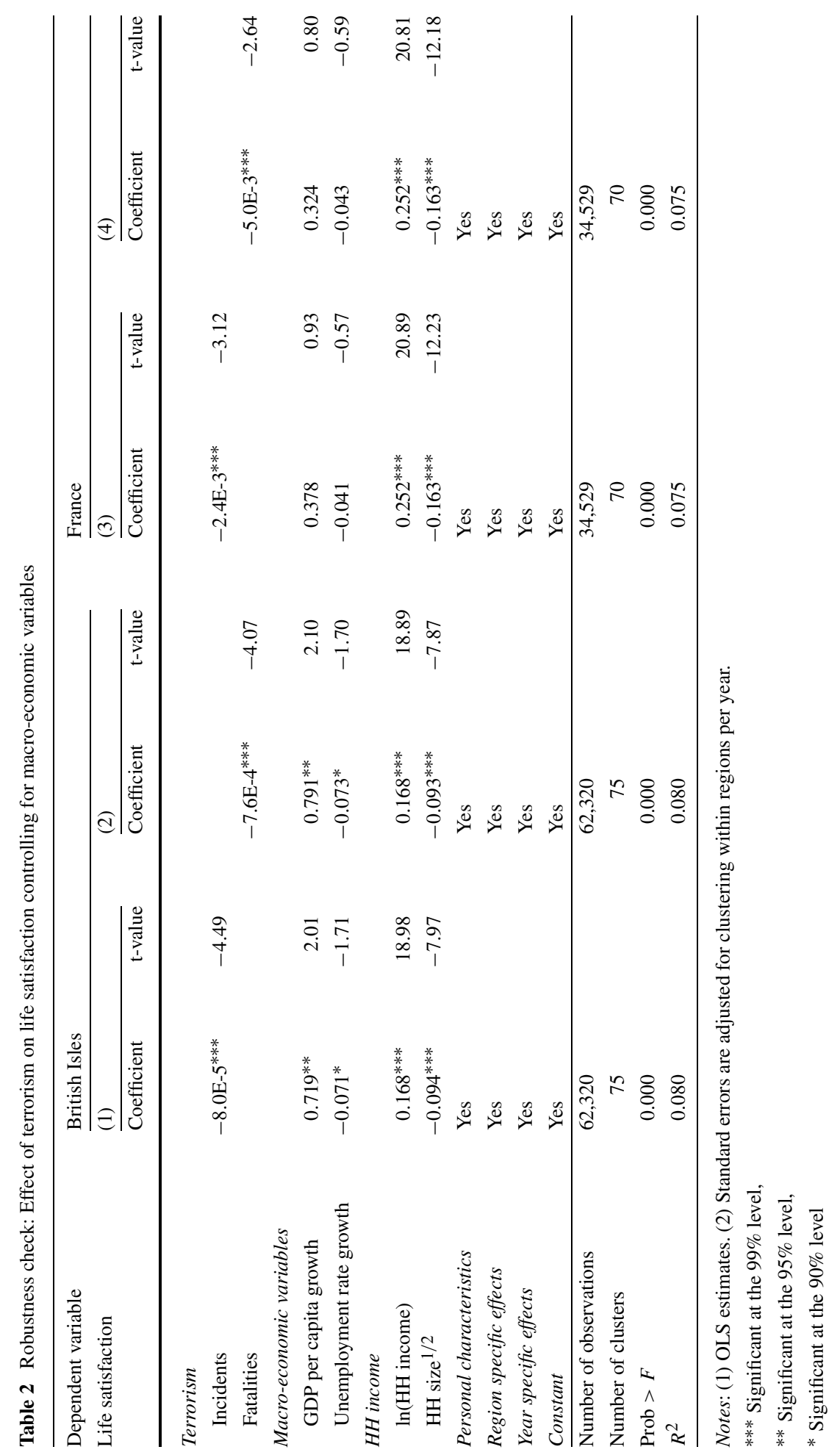


slightly. In the case of the British Isles, the coefficient for the number of incidents increases by $5 \%$, and the coefficient for the number of fatalities by $19 \%$. In the case of France, the coefficient for the number of incidents increases by $9 \%$, whereby an increase of $3 \%$ is due to the change in the sample, and an increase of $6 \%$ is due to the inclusion of macro-economic variables. The coefficient for the number of fatalities remains constant because the change due to the adjusted sample and the change due to the inclusion of the macro-economic variables offset each other; the former amounts to $-4 \%$, and the latter to $+4 \%$. Thus, neither does the course of the economy spuriously cause the negative correlation between terrorism and life satisfaction, nor are the contemporaneous economic effects of terrorism an important channel through which terrorism affects life satisfaction. Note though that household income and individual employment status have already been included in the baseline estimations.

The regions specific macro-economic variables have the expected effect on life satisfaction, but only in a statistically significant way in the sample for the British Isles.

\subsubsection{Differential effects for different sub-groups of the population}

We estimate differential effects of terrorism on life satisfaction for different sub-groups as an additional means of addressing potential simultaneity problems. If terrorism is found to affect different groups differently in a way that corresponds to prior expectations, this enhances our confidence that the estimated correlations are not caused by simultaneous and spatially coincident shocks. Unlike terrorism, these shocks are assumed to have the same effect on all sub-groups. The problem with this approach is to find groups that are likely to suffer disproportionately from terrorism. Terrorist attacks kill people indiscriminately and unpredictably. Bombs exploding on the Paris metro or wrecking crowded pubs in Birmingham kill people from all walks of life. In Northern Ireland, people were killed randomly in so-called "doorstep killings" whereby victims were shot on answering the door. Even wider is the circle of the bereaved. Although a majority of the victims of the Northern Ireland conflict were male and young (Fay et al. 1999, pp. 161-163), we do not find larger effects of terrorism on life satisfaction for these groups, probably because they are under-represented among the bereaved.

We identify three sub-groups. First, we hypothesize respondents living in rural areas to be less affected than respondents living in towns and cities. Terrorists often strike in cities in order to increase the death toll and secure media attention. In Northern Ireland, some scholars distinguish a "rural war" from other types of conflicts. This war was fought between the protagonists themselves and resulted in a remarkably different profile of victims: "[...] a high proportion of casualties were members of the security forces who did not live in the area" (Fay et al. 1999, p. 143). Therefore, fear, empathy and grief are expected to be lower among rural residents. Second, social psychology demonstrates that religiosity plays an outstanding role in the list of factors that help people cope with the threat of terrorism (Peterson and Seligman 2003; Fischer et al. 2006). Hence, we expect self-reported agnostics and atheists to suffer more from terrorism. Finally, in the case of Northern Ireland, Catholics were at greater risk of being injured or killed in both absolute and relative terms (Fay et al. 1999, p. 165). Thus the third differentiation is with regard to denomination. The results are reported in Table 3. Because the information on the type of living area and religious denomination is not included in all waves of the Euro-Barometer Survey Series, Table 3 also contains the effect of terrorism on life satisfaction for the whole population in the respective sub-samples.

As can be seen from Table 3, the estimates are consistent with the hypotheses. The effect of terrorism on life satisfaction for people living in rural areas is only between one half 


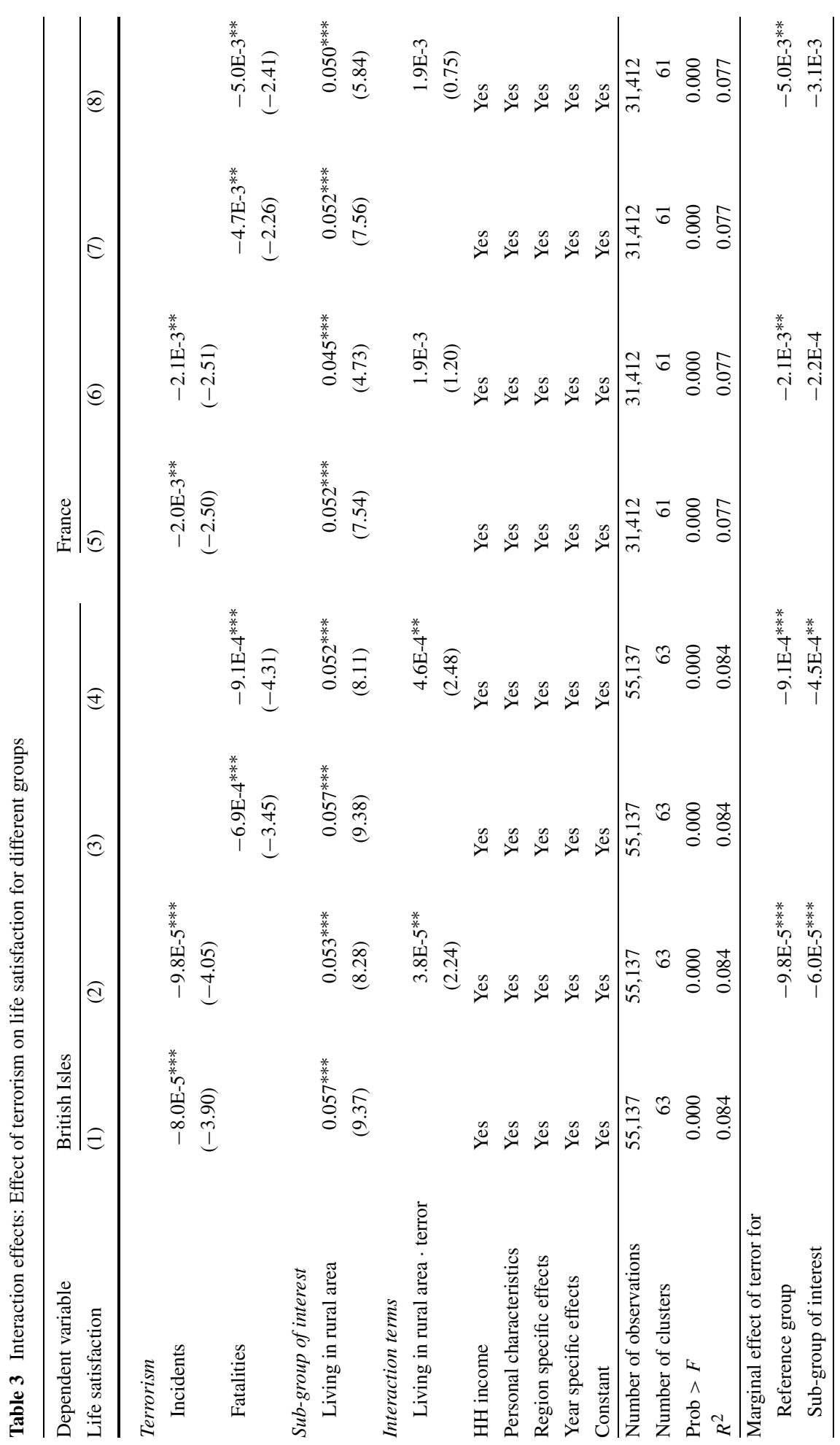




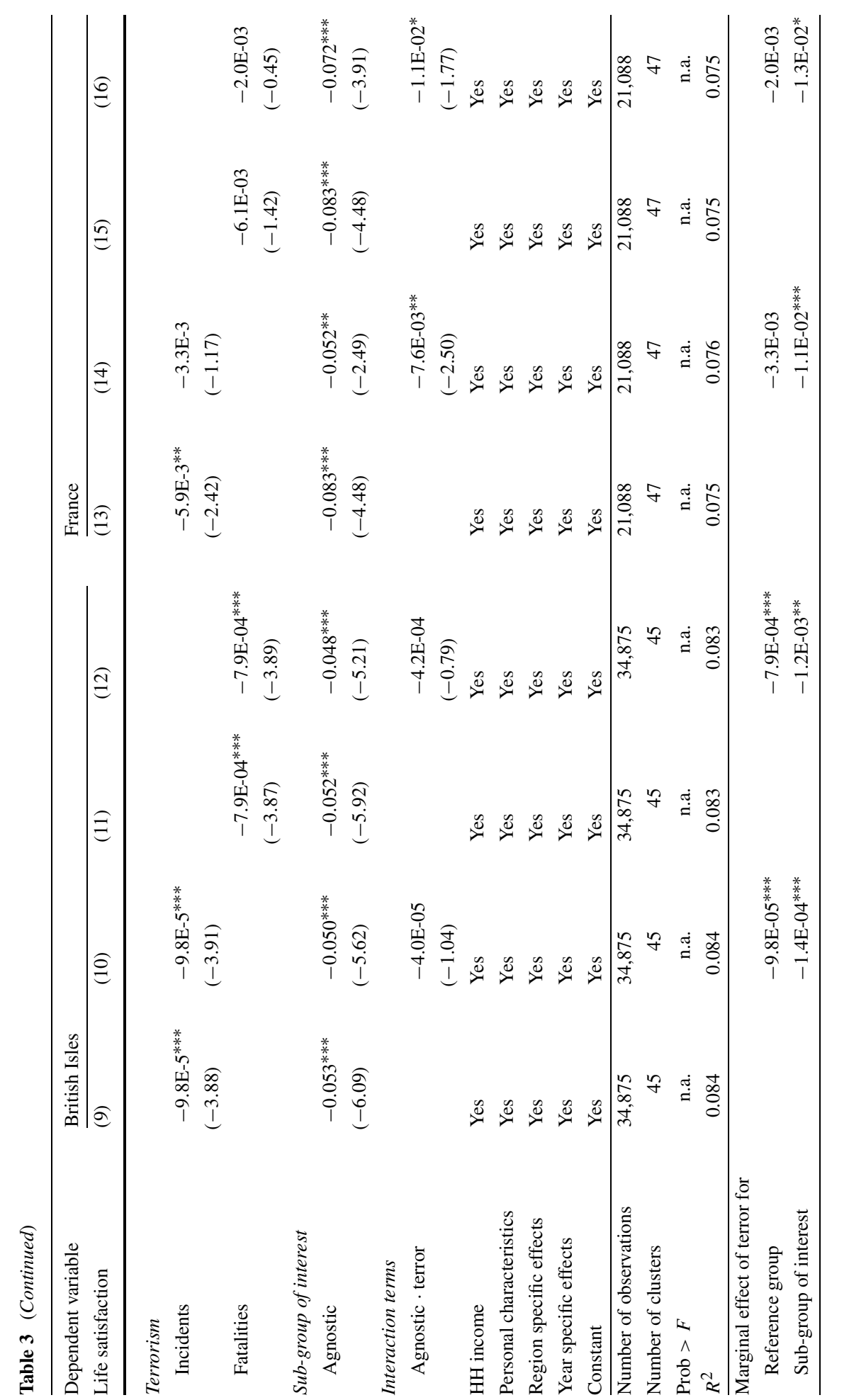


Table 3 (Continued)

\begin{tabular}{|c|c|c|}
\hline \multirow{2}{*}{$\begin{array}{l}\text { Dependent variable } \\
\text { Life satisfaction }\end{array}$} & \multicolumn{2}{|l|}{ British Isles } \\
\hline & $(17)$ & $(18)$ \\
\hline \multicolumn{3}{|l|}{ Terrorism } \\
\hline Incidents & $\begin{array}{l}-9.5 \mathrm{E}-5^{* * *} \\
(-3.40)\end{array}$ & \\
\hline Fatalities & & $\begin{array}{l}-7.5 \mathrm{E}-04^{* * *} \\
(-3.44)\end{array}$ \\
\hline \multicolumn{3}{|l|}{ Sub-group of interest } \\
\hline Catholic & $\begin{array}{l}-0.004 \\
(-0.37)\end{array}$ & $\begin{array}{c}0.000 \\
(0.00)\end{array}$ \\
\hline \multicolumn{3}{|l|}{ Interaction terms } \\
\hline Catholic $\cdot$ terror & $\begin{array}{l}-1.3 \mathrm{E}-5 \\
(-0.74)\end{array}$ & $\begin{array}{l}-2.1 \mathrm{E}-4 \\
(-1.04)\end{array}$ \\
\hline $\mathrm{HH}$ income & Yes & Yes \\
\hline Personal characteristics & Yes & Yes \\
\hline Region specific effects & Yes & Yes \\
\hline Year specific effects & Yes & Yes \\
\hline Constant & Yes & Yes \\
\hline Number of observations & 34,875 & 34,875 \\
\hline Number of clusters & 45 & 45 \\
\hline Prob $>F$ & n.a. & n.a. \\
\hline$R^{2}$ & 0.084 & 0.083 \\
\hline \multicolumn{3}{|c|}{ Marginal effect of terror for } \\
\hline reference group & $-9.5 \mathrm{E}-05^{* * *}$ & $-7.5 \mathrm{E}-04^{* * *}$ \\
\hline sub-group of interest & $-1.1 \mathrm{E}-04^{* * *}$ & $-9.6 \mathrm{E}-04^{* * *}$ \\
\hline
\end{tabular}

Notes: (1) OLS estimates. (2) t-values are in parentheses. (3) Standard errors are adjusted for clustering within regions per year.

*** Significant at the $99 \%$ level

** Significant at the $95 \%$ level

* Significant at the $90 \%$ level

and two thirds of the size of the effect for people living in urban areas; for the number of incidents in France, the negative effect vanishes almost entirely. According to all models, agnostics are more heavily affected by terrorism than their religious counterparts, in the British Isles by a factor of 1.5, in France by a factor of 3.3 to 6.5. Finally, Catholics suffer more from political violence in the British Isles, although the difference is less pronounced compared to the other subgroup effects.

\subsection{Monetization}

With the estimated coefficients of the micro-econometric life satisfaction functions for terrorism $\left(\hat{\beta}_{1}\right)$ and income $\left(\hat{\beta}_{2}\right)$, people's implicit willingness-to-pay for a reduction in terrorism can be calculated. Willingness-to-pay is measured by the compensating surplus $(C S)$. The $C S$ is the decrease in income necessary to hold utility constant. In other words, the $C S$ 
is the solution to the following expression:

$$
v\left(m_{i 0} ; T_{i 0}\right)=v\left(m_{i 0}-C S ; T_{i 1}\right),
$$

where $v(\cdot)$ is the utility function, $m_{r 0}$ the initial household income, $T_{i 0}$ the initial level of terrorism and $T_{i 1}$ the level after a hypothetical reduction. According to the specification of the micro-econometric happiness function expressed in (1) and the definition of the $C S$ in (2), the $C S$ can be computed as follows:

$$
C S=m_{i 0}\left(1-\exp \left(\hat{\beta}_{1} \cdot \hat{\beta}_{2}^{-1} \cdot \Delta T_{i}\right)\right) .
$$

Estimates are presented for people living in particular terrorism-prone regions. Specifically, we calculate the hypothetical willingness-to-pay of residents in Paris and Northern Ireland for a reduction in the number of incidents and the number of fatalities to bring them on a par with the rest of France (except for the region Provence-Alpes-Côte d'Azur) and the rest of Great Britain respectively. All CSs are calculated for an individual with the average annual household income. The results reported in Table 4 are based on coefficients from least square estimations (Table 1) and from ordered probit estimations (available on request).

According to the results shown in Table 4, for a reduction in terrorist activity to a level that prevails in the more peaceful parts of the country, a resident of Northern Ireland would be willing to pay between $26 \%$ (if terrorism is measured by the number of fatalities) and $37 \%$ (if terrorism is measured by the number of incidents) of his income. A resident of Paris would be willing to forego between $4 \%$ (number of fatalities) and $8 \%$ (number of incidents) of his income. As can be seen from Table 4, ordered probit estimations produce similar results; the respective numbers are $27 \%, 38 \%, 4 \%$ and $8 \%$. Table 4 reports not only the point estimates but also the respective standard errors of the $C S$ estimates. Standard errors are bootstrapped, based on 1,000 repetitions taking into account that $C S$ is calculated based on the ratio of two estimated variables. According to the standard errors and respective confidence intervals, we cannot reject the hypothesis that the two terrorism indicators, the

\begin{tabular}{|c|c|c|c|c|}
\hline \multirow[b]{2}{*}{ Average annual household income } & \multicolumn{2}{|c|}{ British Isles 1975-1998 } & \multicolumn{2}{|c|}{ France $1973-1998$} \\
\hline & $\$ 20,501$ & & $\$ 26,067$ & \\
\hline Reduction of terrorism & $1,022.76$ acts & 77.04 deaths & 9.58 acts & 2.16 deaths \\
\hline \multicolumn{5}{|c|}{ Basis: least square estimations (Table 1) } \\
\hline Compensating surplus (CS) & $\begin{array}{l}\$ 7,641 \\
(\$ 891)\end{array}$ & $\begin{array}{l}\$ 5,252 \\
(\$ 892)\end{array}$ & $\begin{array}{l}\$ 2,149 \\
(\$ 683)\end{array}$ & $\begin{array}{l}\$ 1,099 \\
(\$ 413)\end{array}$ \\
\hline$C S$ in percent of income & $\begin{array}{l}37.3 \% \\
(4.3 \%)\end{array}$ & $\begin{array}{l}25.6 \% \\
(4.4 \%)\end{array}$ & $\begin{array}{l}8.2 \% \\
(2.6 \%)\end{array}$ & $\begin{array}{l}4.2 \% \\
(1.6 \%)\end{array}$ \\
\hline \multicolumn{5}{|l|}{ Basis: ordered probit estimations } \\
\hline Compensating surplus $(C S)$ & $\begin{array}{l}\$ 7,877 \\
(\$ 864)\end{array}$ & $\begin{array}{l}\$ 5,454 \\
(\$ 918)\end{array}$ & $\begin{array}{l}\$ 1,948 \\
(\$ 704)\end{array}$ & $\begin{array}{l}\$ 1,050 \\
(\$ 437)\end{array}$ \\
\hline$C S$ in percent of income & $\begin{array}{l}38.4 \% \\
(4.2 \%)\end{array}$ & $\begin{array}{l}26.6 \% \\
(4.5 \%)\end{array}$ & $\begin{array}{l}7.5 \% \\
(2.7 \%)\end{array}$ & $\begin{array}{l}4.0 \% \\
(1.7 \%)\end{array}$ \\
\hline
\end{tabular}

Table 4 Compensating surplus for a reduction in terrorism

Notes. (1) CS is calculated for residents of Paris and of Northern Ireland for a reduction terrorism to the intensity of terrorism in the more peaceful parts of the respective countries. (2) CS estimates are in 2004 US dollars. (3) Bootstrapped standard errors in parentheses (1000 replications) 
number of fatalities and the number of incidents, generate the same results. For a resident of Northern Ireland, the $95 \%$ confidence interval of the $C S$ for a reduction in the number of fatalities is $17 \%$ to $34 \%$, and the confidence interval for a reduction in the number of incidents is $29 \%$ to $46 \%$. For France, the respective $95 \%$ confidence intervals are $1 \%$ to $7 \%$ and $3 \%$ to $13 \%$. Hence, the CS estimates for France are significantly lower than the CS estimates for the British Isles.

We put the main results for the CSs into perspective. The result for France, on the one hand, is comparable to the compensations which Blomquist et al. (1988) identified on the labor and housing market in the United States for individuals living in the county with the highest rate of violent crime vis à vis individuals living in the county with the least crime. The compensation according to Blomquist et al. (1988) amounts to $\$ 2,267$, or to $11 \%$ of the annual household income.

The result for Northern Ireland, on the other hand, to some extent reflects the ferocity of the conflict. The number of incidents and fatalities depicted in Figs. 3 and 4 give a sense of this ferocity. Fay et al. (1999, p. 204) estimate that around two-thirds of the Northern Irish population live in households where someone has been injured in a conflict-related incident; the number of around 30,000 republican and loyalist ex-prisoners illustrates how deeply society was permeated by paramilitarism (McKittrick and McVea 2001, p. 150).

In addition, curfews, rigorous house-to-house searches, several thousand people fleeing their homes and large-scale riots accompanied the worst times of the conflict. The statements of two senior policemen summarize the situation: "The country stared into the face of great difficulty and crept right to the edge of the abyss," and "We were on the brink of all-out civil war" (cited in McKittrick and McVea 2001, p. 211).

Given the ferocity of this conflict and our high estimate of a $C S$, one might wonder why a mass exodus out of Northern Ireland was not observed. One reason might be that residents of Northern Ireland indeed got massive compensation for living in Northern Ireland: Without invoking a direct relationship to the figures presented in Table 4, transfers from Great Britain to Northern Ireland (excluding defense and courts expenditures) averaged one-fourth of the Northern Irish GDP, or a third of income created in Northern Ireland itself, in the time-period considered.

These subsidies support relatively well-paid jobs in manufacturing (over $90 \%$ of the manufacturing jobs are subsidized) and the public sector. They finance the health and welfare system as well as subsidized housing (Fay et al. 1999, pp. 110-113). Thus, a large proportion of the population in Northern Ireland benefit directly. Additional transfers to Northern Ireland take the form of compensation payments for losses and injuries, expenditures for security and justice, and subsidies from the European Union. (With regard to the identification of utility losses caused by terrorism, it is important to note that these transfers do not vary with the level of terrorist activity.)

However, despite these enormous transfers, numerous people did leave Northern Ireland in reaction to the violence, as Fig. 5 suggests (see also Registrar General Northern Ireland various years).

Another reason for a high CS for lower terrorist activity might be people's difficulty in assessing terrorism-risks. According to Viscusi and Zeckhauser (2003), people are subject to a propensity to predict worst-case scenarios and are prone to anomalies known from other risk perception contexts. Hindsight bias and embeddedness effects are particularly evident for terrorism-risk perception. Downes-Le Guin and Hoffman (1993) contend that much higher probabilities are accorded to terrorism than to other life-threatening acts. Sunstein (2003), on the other hand, finds that individuals focus on the badness of the outcome rather than on the probability that it will occur. The "probability neglect" results in fear that 


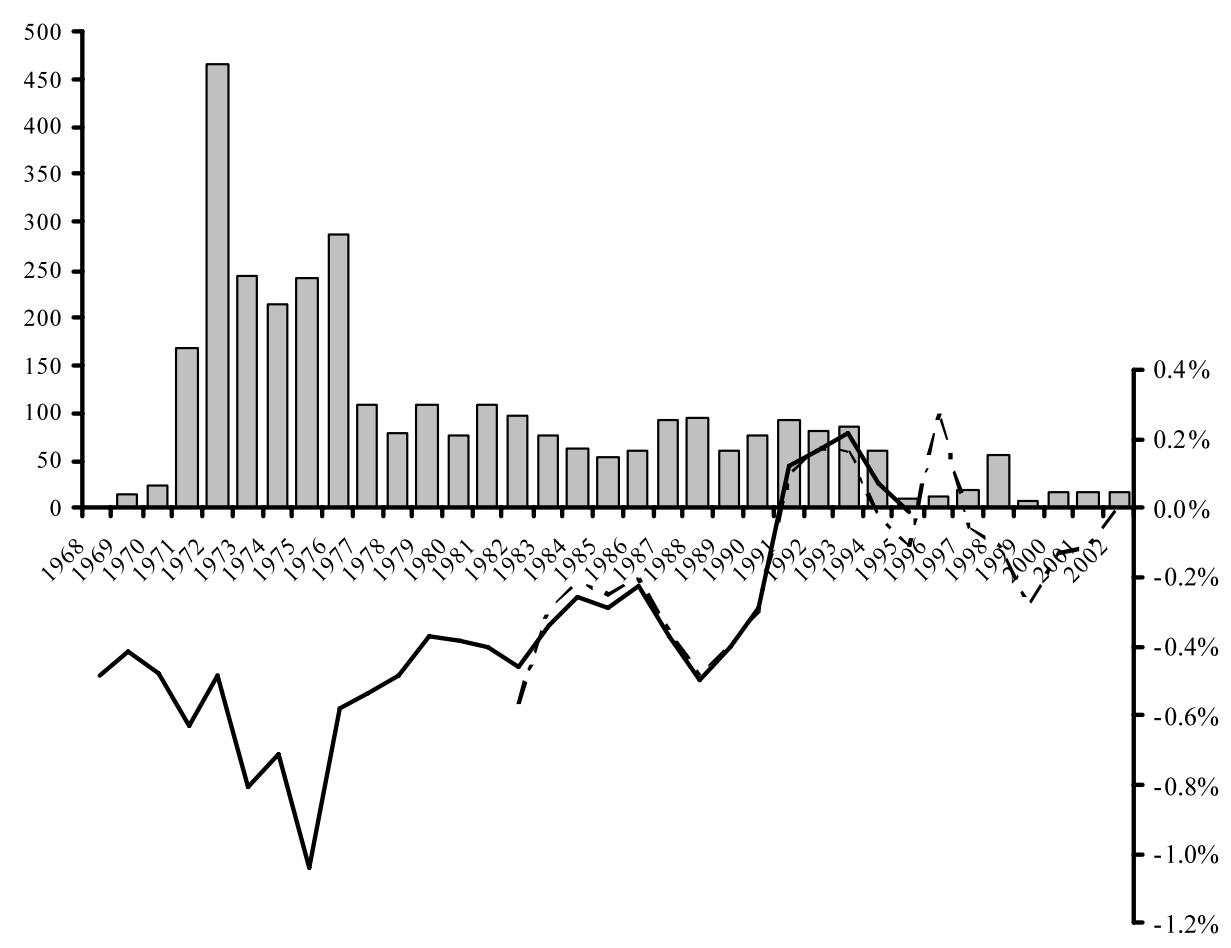

Fig. 5 Fatalities in Northern Ireland and net migration (in \% of population). The Registrar General publishes two overlapping but not entirely consistent series of migration; both are shown in the figure. Sources: Sutton (1994) and an updated version of the Sutton index provided by CAIN Web Service (www.cain.ulst.ac.uk), and Registrar General (various years)

greatly exceeds discounted harm. These results suggest that people are far more concerned with terrorism than with objectively larger risks.

Becker and Rubinstein (2004) also assert that terrorism can have consequences beyond what the underlying probabilities would suggest. But rather than attributing this to cognitive limitations in risk assessing, they base their explanation on an additional "fear factor": An exogenous increase in risk not only affects utility by changing the probabilities, but also by reducing the utility enjoyed from the consumption of risky activities, such as riding a bus after suicide attacks on buses. As Becker and Rubinstein (2004, p. 7) observe, "[b]y generating fear, terror, even in the form of a low probability event, may generate substantial effects." Calibrating a benchmark utility function to fit the data of Israeli bus demand and using commonly accepted values for the risk aversion parameter, they estimate the marginal utility of a bus ride to fall by 10 to $20 \%$ if suicide bomber attacks are carried on buses.

Thus, equating the terrorism with the probability of dying entirely misses the distinctive feature of terrorism, i.e., to spread terror. Whether far-reaching consequences are explained by cognitive limitations or fear, perceptions of terrorism are mainly influenced by the salience of the topic. Intense media coverage of terrorist acts ensures that terrorism is very present in people's minds. The high number of fatalities in violent periods of the conflict in Northern Ireland, for example, means "that hardly a newspaper or evening television programme did not bring news of either a killing or a funeral" (McKittrick and McVea 2001, p. 94), and that "the local television news seemed to consist of nothing except more and more 
violence, the grieving bereaved, and threats of more to come" (McKittrick and McVea 2001, p. 194).

\section{Concluding remarks}

No doubt, terrorism and regional conflict are important sources of misery. There are psychic costs that go far beyond the economic losses from terrorism traditionally studied in economics. But how large are these psychic costs? We apply the LSA as a tool to value the overall social costs of terrorism.

People's welfare losses caused by terrorist activity are estimated, based on panel data for terrorist attacks and fatalities and reported life satisfaction between 1973/75 and 2002 . The results for France and the British Isles demonstrate that terrorist campaigns depress the life satisfaction of the individuals in the affected regions in a sizeable way. For a change in fatalities by one standard deviation in France, the effect amounts to 1/44 of the reduction in life satisfaction when unemployed rather than employed or self-employed. The respective ratio is $1 / 23$ for the British Isles. Calculating $C S \mathrm{~s}$, the costs of terrorism are around $4 \%$ of annual household income in France and around $26 \%$ in the British Isles when the most terrorist prone regions are compared to the least terrorist prone regions. The effects of terrorism are robust when controlling for possible simultaneity of terrorism and adverse economic conditions.

We see the LSA as a promising approach for the valuation of important non-monetary costs of conflicts but also for the valuation of public goods and bads in general. In addition to any overall valuation, net distributional consequences of the provision of some public good can be studied. In our empirical analysis, for example, people living in urban areas rather than rural areas suffer more from terrorism. While overall valuations can provide valuable information for cost-benefit analyses, findings for differential effects can help to understand the intensity of support for the provision of some public goods in the political process. We expect many new insights from research in both directions in the near future.

Acknowledgements We are grateful for helpful comments from Andrew Clark, A. Myrick Freeman, Ed Glaeser, Lorenz Goette, Bas Jacobs, Stephan Meier, Robert Metcalfe, Dina Pomeranz, Friedrich Schneider, Rainer Winkelmann, three anonymous referees, the participants of the European Public Choice Meeting 2004, the CESifo Area Conference on Public Sector Economics, the Annual Meeting 2005 of the Verein für Socialpolitik, and the 12th Munich Lectures in Economics 2005.

\section{References}

Abadie, A. (2006). Poverty, political freedom, and the roots of terrorism. American Economic Review, 96(2), 50-56.

Abadie, A., \& Gardeazabal, J. (2003). The economic costs of conflict: A case study of the Basque Country. American Economic Review, 93(1), 113-132.

Arrow, K. J. (1958). Utilities, attitudes, choices: A review note. Econometrica, 26(10), 1-23.

Becker, G. S., \& Rubinstein, Y. (2004). Fear and the response to terrorism: An economic analysis. Mimeo, University of Chicago.

Berrebi, C. Evidence about the link between education, poverty and terrorism among Palestinians. Peace Economics, Peace Science and Public Policy, 13(1) (2003), article 2.

Blanchflower, D. G., \& Oswald, A. J. (2007). Hypertension and happiness across nations. IZA Discussion paper, Series No. 2633, IZA, Bonn.

Blomquist, G. C., Berger, M. C., \& Hoehn, J. P. (1988). New estimates of quality of life in urban areas. American Economic Review, 78(1), 89-107. 
Clark, A. E., Frijters, P., \& Shields, M. A. (2008). Relative income, happiness and utility: An explanation for the Easterlin Paradox and other puzzles. Journal of Economic Literature, 46(1), 95-144.

Diener, E., Suh, E. M., Lucas, R. E., \& Smith, H. L. (1999). Subjective well-being: Three decades of progress. Psychological Bulletin, 125(2), 276-302.

Di Tella, R., \& MacCulloch, R. J. (2006). Some uses of happiness data in economics. Journal of Economic Perspectives, 20(1), 25-46.

Downes-Le Guin, T., \& Hoffman, B. (1993). The impact of terrorism on public opinion, 1988 to 1989. RAND Corporation, Santa Monica, CA.

Due, J. F., \& Friedlaender, A. F. (1973). Government finance: Economics of the public sector, 5th ed. Homewood: Irwin.

Elster, J., \& Roemer, J. E. (eds.) (1991). Interpersonal comparisons of well-being. Studies in rationality and social change. Cambridge: Cambridge University Press.

Enders, W., \& Sandler, T. (1991). Causality between transnational terrorism and tourism: The case of Spain. Terrorism, 14(1), 49-58.

Enders, W., \& Sandler, T. (1995). Terorism: Theory and applications. In K. Hartley \& T. Sandler (Eds.), Handbook of defense economics (Vol. 1, pp. 213-249). Amsterdam: Elsevier.

Enders, W., \& Sandler, T. (2006). The political economy of terrorism. Cambridge: Cambridge University Press.

Engene, J. O. (2007). Five decades of terrorism in Europe: The TWEED dataset. Journal of Peace Research, 44(1), 109-121.

Fay, M.-T., Morrissey, M., \& Smyth, M. (1999). Northern Ireland's troubles: The human costs. London: Pluto Press.

Ferrer-i-Carbonell, A., \& Frijters, P. (2004). How important is methodology for the estimates of the determinants of happiness? Economic Journal, 114(497), 641-659.

Fielding, D. (2003). Investment, employment, and political conflict in Northern Ireland. Oxford Economic Papers, 55(3), 512-535.

Fischer, P., Greitemeyer, T., Kastenmuller, A., Jonas, E., \& Frey, D. (2006). Coping with terrorism: The impact of increased salience of terrorism on mood and self-efficacy of intrinsically religious and nonreligious people. Personality and Social Psychology Bulletin, 32(3), 365-377.

Frey, B. S. (2004). Dealing with terrorism-stick or carrot? Cheltenham/Northampton: Edward Elgar.

Frey, B. S., \& Luechinger, S. (2003). How to fight terrorism: Alternatives to deterrence. Defence and Peace Economics, 14(4), 237-249.

Frey, B. S., \& Stutzer, A. (2000). Happiness, economy and institutions. Economic Journal, 110(466), 918938.

Frey, B. S., \& Stutzer, A. (2002a). Happiness and economics: How the economy and institutions affect wellbeing. Princeton: Princeton University Press.

Frey, B. S., \& Stutzer, A. (2002b). What can economists learn from happiness research? Journal of Economic Literature, 40(2), 402-435.

Frey, B. S., \& Stutzer, A. (2005). Testing theories of happiness. In L. Bruni \& P. Porta (Eds.), Economics and happiness. Framing the analysis (pp. 116-146). Oxford: Oxford University Press.

Frey, B. S., Luechinger, S., \& Stutzer, A. (2007). Calculating tragedy: Assessing the costs of terrorism. Journal of Economic Surveys, 21(1), 1-24.

Hoffman, B. (1998). Inside terrorism. New York: Columbia University Press.

Hoffman, B., \& Hoffman, D. K. (1995). The RAND-St. Andrews chronology of international terrorism 1994. Terrorism and Political Violence, 7(4), 178-229.

Kahneman, D., Diener, E., \& Schwarz, N. (Eds.) (1999). Well-being: The foundations of hedonic psychology. New York: Russell Sage Foundation.

Kahneman, D., \& Thaler, R. H. (2006). Anomalies: Utility maximization and experienced utility. Journal of Economic Perspectives, 20(1), 221-234.

Kahneman, D., Wakker, P. P., \& Sarin, R. (1997). Back to Bentham? Explorations of experienced utility. Quarterly Journal of Economics, 112(2), 375-405.

Kimball, M., \& Willis, R. (2006). Utility and happiness. Mimeo, University of Michigan.

Koivumaa-Honkanen, H., Honkanen, R., Viinamäki, H., Heikkilä, K., Kaprio, J., \& Koskenvuo, M. (2001). Life satisfaction and suicide: A 20-year follow-up study. American Journal of Psychiatry, 158(3), 433439.

Krueger, A. B., \& Laitin, D. D. (2003). Kto kogo?: A cross-country study of the origins and targets of terrorism. In P. Keefer \& N. Loayza (Eds.), Terrorism, economic development, and political openness (pp. 178-173). Cambridge: Cambridge University Press.

Krueger, A. B., \& Maleckova, J. (2003). Education, poverty and terrorism: Is there a causal connection? Journal of Economic Perspectives, 17(4), 119-144. 
Kurrild-Klitgaard, P., Justesen, M.K., \& Klemmensen, R. (2006). The political economy of freedom, democracy and transnational terrorism. Public Choice, 128(1-2), 289-315.

Lepper, H. S. (1998). Use of other-reports to validate subjective well-being measures. Social Indicators Research, 44(3), 367-379.

Luechinger, S. (2008). Valuing air quality using the life satisfaction approach. Mimeo, University of Zurich.

Luechinger, S., \& Raschky, P. (2008). Valuing flood disasters using the life satisfaction approach. Mimeo, University of Zurich.

McKittrick, D., \& McVea, D. (2001). Making sense of the troubles. London: Penguin Books.

Peterson, C. P., \& Seligman, M. E. P. (2003). Character strengths before and after September 11. Psychological Science, 14(4), 381-384.

Piazza, J. A. (2006). Rooted in poverty? Terrorism, poor economic development, and social cleavages. Terrorism and Political Violence, 18(1), 159-177.

Registrar General Northern Ireland. (various years). Annual report. Northern Ireland Statistics and Research Agency, Belfast.

Rowley, C. K. (2006). Terrorist attacks on Western civilization. Public Choice, 128(1-2), 1-6.

Sandler, T., Arce, D. G., \& Enders, W. (2008). Terrorism. Copenhagen Consensus 2008. Challenge paper, Copenhagen Consensus Center, Copenhagen.

Schelling, T. C. (1968). The life you save may be your own. In S. B. Chase (Ed.), Problems in public expenditure analysis (pp. 127-176). Washington: The Brookings Institution.

Shughart, W. F. (2006). An analytical history of terrorism, 1945-2000. Public Choice, 128(1-2), 7-39.

Sen, A. K. (1986). The standard of living. In S. McMurrin (Ed.), Tanner lectures on human values (Vol. III). Cambridge: Cambridge University Press.

Sunstein, C. R. (2003). Terrorism and probability neglect. Journal of Risk and Uncertainty, 26(2-3), 121136.

Sutton, M. (1994). Bear in mind these dead .... An index of deaths from the conflict in Ireland 1969-1993. Belfast: Beyond the Pale Publications.

Urry, H. L., Nitschke, J. B., Dolski, I., Jackson, D. C., Dalton, K. M., Mueller, C. J., Rosenkranz, M. A., Ryff, C. D., Singer, B. H., \& Davidson, R. J. (2004). Making a life worth living: Neural correlates of well-being. Psychological Science, 15(6), 367-372.

Van Praag, B. M. S., \& Baarsma, B. E. (2005). Using happiness surveys to value intangibles: The case of airport noise. Economic Journal, 115(500), 224-246.

Viscusi, W. K., \& Zeckhauser, R. J. (2003). Sacrificing civil liberties to reduce terrorism risks. Journal of Risk and Uncertainty, 26(2-3), 99-120.

Welsch, H. (2002). Preferences over prosperity and pollution: Environmental valuation based on happiness surveys. Kyklos, 55(4), 473-494.

Wilkinson, P. (2000). Terrorism versus democracy: The liberal state response. London/Portland: Frank Cass. 